\title{
Heat tolerance of early developmental stages of glacier foreland species in the growth chamber and in the field
}

\author{
Silvia Marcante • Brigitta Erschbamer • \\ Othmar Buchner • Gilbert Neuner
}

Received: 21 February 2014/ Accepted: 3 May 2014/Published online: 2 July 2014

(C) The Author(s) 2014. This article is published with open access at Springerlink.com

\begin{abstract}
In glacier forelands, seeds readily germinate, however, a high proportion of seedlings die shortly after their appearance. We hypothesized that besides drought, frost and missing safe sites, heat on the ground surface could be one of the major threats for seedlings. The heat strain in different ground strata was assessed from 2007 to 2010 . The heat tolerance $\left(\mathrm{LT}_{50}\right)$ of eleven alpine species from different successional stages was tested considering imbibed (G1) and germinated seeds (G2) as well as seedlings (G3). Additionally, the heat hardening capacity of seedlings was determined in the field. Across all species, $\mathrm{LT}_{50}$ decreased significantly by $9 \mathrm{~K}$ from $\mathrm{G} 1\left(55^{\circ} \mathrm{C}\right)$ to $\mathrm{G} 3\left(46{ }^{\circ} \mathrm{C}\right)$, similarly in all
\end{abstract}

Communicated by Thomas Abeli, Anne Jäkäläniemi and Rodolfo Gentili.

Electronic supplementary material The online version of this article (doi:10.1007/s11258-014-0361-8) contains supplementary material, which is available to authorized users.

S. Marcante - B. Erschbamer · O. Buchner .

G. Neuner $(\square)$

Institute of Botany, University of Innsbruck,

Sternwartestrasse 15, 6020 Innsbruck, Austria

e-mail: Gilbert.Neuner@uibk.ac.at

S. Marcante

e-mail: Silvia.Marcante@uibk.ac.at

B. Erschbamer

e-mail: Brigitta.Erschbamer@uibk.ac.at

O. Buchner

e-mail: Othmar.Buchner@uibk.ac.at species of the successional stages. Field-grown seedlings had mostly an increased $\mathrm{LT}_{50}(2 \mathrm{~K})$. Intraspecifically, $\mathrm{LT}_{50}$ of seedlings varied between 40.6 and $52.5^{\circ} \mathrm{C}$. Along the chronosequence, $\mathrm{LT}_{50}$ in $\mathrm{G} 1$ was similar, but was higher in G2 and G3 of early successional species. The highest temperatures occurred at $0-0.5 \mathrm{~cm}$ in air (mean/absolute maximum: $42.6 / 54.1{ }^{\circ} \mathrm{C}$ ) posing a significant heat injury risk for seedlings when under water shortage transpirational cooling is prevented. Below small stones $(0-0.5 \mathrm{~cm})$, maxima were $4 \mathrm{~K}$ lower, indicating heat safer microsites. Maxima $>30{ }^{\circ} \mathrm{C}$ occurred at $32.3,>40{ }^{\circ} \mathrm{C}$ at $6.2 \%$. Interannually, 2010 was the hottest year with heat exceeding $\mathrm{LT}_{50}$ at all microsites $(0-0.5 \mathrm{~cm})$. Temperature maxima on sandy surfaces were lower than on microsites with gravel (diameter $<5-10 \mathrm{~mm}$ ). The hot summer of 2010 may be a small foretaste of in future more severe and frequent heat waves. Ground surface temperature maxima at the pioneer stage are already now critical for heat survival and may partly explain the high seedling mortality recognized on recently deglaciated terrain.

Keywords Alpine plants - Germination · Heat tolerance $\cdot$ Risk assessment $\cdot$ Seeds $\cdot$ Temperature stress

\section{Introduction}

Maximum free air temperatures are too low to cause heat damage to plants above the treeline in temperate- 
zone mountains. However, alpine plants often show a prostrate growth that causes a decoupling from ambient air temperature. Depending on plant stature, plant body temperatures can exceed air temperature by 20-30 K (Salisbury and Spomer 1964; Körner and Cochrane 1983; Gauslaa 1984; Körner 2003; Larcher and Wagner 2009, 2010; Larcher 2012; Neuner and Buchner 2012). The maximum plant body temperatures found during summer in the field actually come close to the observed heat tolerance of alpine plant species (Körner 2003). Vegetative above-ground plant parts of alpine species get damaged by heat between 42 and $64{ }^{\circ} \mathrm{C}$ (Neuner and Buchner 2012) which indeed has occasionally been observed to occur naturally at alpine field sites (Loiseleuria procumbens and Carex firma, Larcher and Wagner 1976; Saxifraga paniculata, Neuner et al. 1999; Minuartia recurva, Buchner and Neuner 2003; Silene acaulis, Gauslaa 1984; Körner 2003). Particularly, in prostrate plants growing in isolation or with large spacing in shallow soil during dry periods with full sunshine, the risk of damage by heat is increased. On bare spots without evaporative cooling, dry soil surfaces can heat up in extreme even to $80^{\circ} \mathrm{C}$ near the alpine timberline (Turner 1958; Körner and Cochrane 1983) and patches of bare humic soil within alpine vegetation appeared likely to be related to heat stress (Körner 2003).

While heat tolerance of adult alpine plants of vegetative above-ground organs (reviewed by Neuner and Buchner 2012) and reproductive structures (Ladinig, Neuner and Wagner unpubl.) in adult alpine plants is well understood, hardly any information exists about the heat susceptibility of germinating seeds and early developmental stages (seedlings and juvenile plants) and of vegetative dispersal units such as plantlets or bulbils. To our knowledge, only a preliminary study has addressed this question to some extent. This study, investigating four alpine plants (Wildner-Eccher and Larcher, unpublished; cited in Neuner and Buchner 2012), suggests significant differences to the heat tolerance of vegetative parts of adult plants: (1) early developmental stages having a tentatively lower heat tolerance than adults; (2) dry seeds showing a significantly increased heat tolerance compared to vegetative shoots of adults but being unable to survive peak soil surface temperatures $\left(\mathrm{cf} .80^{\circ} \mathrm{C}\right.$ ) reported for the respective altitudes of the Central European Alps.

In the glacier foreland on recently deglaciated terrain, germination and establishment of young plants take place on bare ground. Although a considerable number of seeds readily germinates (Niederfriniger Schlag and Erschbamer 2000; Marcante et al. 2009a), establishment occurs only at very low rates as seedling mortality is high (Niederfriniger Schlag and Erschbamer 2000; Welling et al. 2005; Erschbamer et al. 2008; Marcante et al. 2009a). While the low frost resistance during and after germination may at least in certain years explain the high seedling mortality rates (Marcante et al. 2012), also other abiotic and/or biotic factors must play an important role in this respect (Matthews 1992; Erschbamer et al. 2008; Marcante et al. 2009a). One possible explanation for the high seedling mortality rates could be heat stress perceptible on the surface of bare ground. During short dry periods within the growing season, these heat effects will additionally get aggravated when cooling by transpiration is reduced. Heat waves such as that in 2003 (García-Herrera et al. 2010) seriously affect plants growing at high altitudes (Abeli et al. 2012) influencing seed persistence and germination (Walck et al. 2011). On bare ground surfaces of a glacier foreland, we expect that critically high heat events may occur also in 'common' summers, but will be even pronounced in heat wave years (Barriopedro et al. 2011).

Survival of abiotic stress may highly depend on the availability of specific microsites and the presence of safe sites (Choler et al. 2001; Callaway et al. 2002; Kikvidze et al. 2005; Callaway 2007). Soil particle sizes (Chambers et al. 1991) and microrelief govern seedling recruitment in the glacier foreland (Niederfriniger Schlag and Erschbamer 2000; Erschbamer et al. 2008). We hypothesize that these parameters control also the temperature pattern at the ground surface and thus enhance or lower the heat stress for the seedlings.

In the present study, we investigate heat tolerance of imbibed seeds, germinated seeds and seedlings of glacier foreland plants, comparing pioneers, early and late successional species. By linking heat tolerance with temperature maxima in their habitat for the years 2007-2010, the potential risk of suffering heat damage during different developmental stages should be assessed. We addressed the following questions: (1) are there differences in the heat tolerance of glacier foreland species and which organs are the most susceptible ones? (2) What is the maximum air temperature a seedling experiences in the pioneer stage of the glacier foreland and do seedlings have a 
heat hardening capacity in the field? (3) How does the microsite affect maximum air temperature at the ground surface? (4) At what frequency may early developmental stages get exposed to high air temperatures in the glacier foreland and at what probability will they suffer from heat damage under water shortage?

\section{Materials and methods}

Plant material

Eleven alpine plant species (Table 1), all of which occur along the primary succession of the Rotmoos glacier foreland (Obergurgl, Ötztal, Tyrol, Austria, $46^{\circ} 49^{\prime} \mathrm{N} 11^{\circ} 02^{\prime} \mathrm{E}$ ), were selected. In 2008 , per species, almost 500 seeds were collected at the distribution centre of the species (according to the species scores in the CCA plot, Schwienbacher et al. 2012) along the chronosequence (Table 1), i.e. on the pioneer stage (moraine 1971), early successional stage (moraine 1923) and on the late successional stage (moraine 1858). For detailed site descriptions, see Raffl and Erschbamer (2004) and Raffl et al. (2006). Prior to the heat tolerance test, seeds of all species were sown into Petri dishes and cultivated in a growth chamber (Sanyo, E\&E Europe BV, Leicestershire, UK; MLR$350 \mathrm{H} ; 25 / 10{ }^{\circ} \mathrm{C}, 16 / 8 \mathrm{~h}$ light/dark, $400 \mu \mathrm{mol}$ photons $\mathrm{m}^{-2} \mathrm{~s}^{-1}$ ) to the respective development stages.

Table 1 Occurrence of the eleven investigated alpine plant species on three successional stages (pioneer, early and late) of the Rotmoos glacier foreland deglaciated since 1971, 1923, 1858, respectively, and abbreviations used in the text

\begin{tabular}{lll}
\hline Successional stage & Plant species & Abbreviation \\
\hline Pioneer & Saxifraga aizoides & SAXAIZ \\
& Artemisia genipi & ARTGEN \\
& Oxyria digyna & OXYDIG \\
& Arabis coerulea & ARACOE \\
& Trifolium pallescens & TRIPAL \\
Early & Persicaria vivipara & PERVIV \\
& Geum reptans & GEUREP \\
& Poa alpina & POAALP \\
& Leontodon hispidus & LEOHIS \\
Late & Achillea moschata & ACHMOS \\
& Silene acaulis agg. & SILACA \\
\hline
\end{tabular}

The nomenclature follows Fischer et al. (2008)
To test the natural heat tolerance, seedlings were additionally germinated at the research site on the 1971 moraine (i.e. pioneer stage, 2,400 m asl), being ideal due to the presence of large bare ground areas and due to the possibility of artificial irrigation (Schwienbacher et al., unpubl.). In autumn 2008, two bare ground plots were prepared with the natural substrate characteristic for this successional stage. A total of 100 seeds per species per plot were sown in rows of $5 \mathrm{~cm}$ width (one row per species), the row being separated by $10 \mathrm{~cm}$. To prevent drought stress to seedlings and to ensure low mortality rates, the plots were irrigated daily twice by a self-constructed automatic irrigation system using spring water. This should ensure availability of sufficient field-grown seedlings for the experiments in 2009. Bulbils of Persicaria vivipara were regarded as seeds, as they occur in the seed bank of the Rotmoos glacier foreland (Marcante et al. 2009b). To prevent drought stress to seedlings and to ensure low mortality rates, the experimental field was regularly watered during the 2009 growing season.

\section{Developmental stages}

The following development stages were investigated: seeds (G1, imbibed seeds), germinated seeds (G2, emerged radicle at least $2 \mathrm{~mm}$ long) and seedlings (G3, cotyledons completely expanded). To test heat tolerance of germinated seeds and seedlings, seeds were germinated in the growth chamber under standard conditions $\left(25 / 10{ }^{\circ} \mathrm{C}, 16 / 8 \mathrm{~h}\right.$ light/darkness, $400 \mu \mathrm{mol}$ photons $\mathrm{m}^{-2} \mathrm{~s}^{-1}$ ) and then cultivated in the laboratory.

\section{Microclimate}

Throughout four successive summer periods (2007-2010), a microclimate station was operated at the pioneer stage of the Rotmoos glacier foreland (moraine 1971, 2,400 m asl). At the microsites where seedlings establish, temperatures were recorded in order to assess the frequency, duration and severity of heat events. Temperature sensors were positioned at random within an area of $60 \mathrm{~m}^{2}$ at the pioneer stage of the Rotmoos glacier foreland on a plain, bare ground site. Micropositioning of the temperature sensors were chosen such as the sensors were placed on bare ground surfaces close to the artificial irrigation experiment carried out from 2007 till 2010 on this site 
(Schwienbacher et al. unpubl., FWF-project P19090B16). Air temperatures $(1 \mathrm{~cm}$ above the ground surface; five sensors), ground surface temperatures $(0-0.5 \mathrm{~cm}$; sensor tip in air: 14 sensors; sensor tip below small stones: six sensors) and soil temperatures ( $-0.5 \mathrm{~cm}$; two sensors) were measured with thermocouple sensors (Type T, solder junction diameter: $0.2 \mathrm{~mm}$, TT-Ti 36, Omega, Stamford, USA). For ground surface temperatures $(0-0.5 \mathrm{~cm})$, the grain size at the microsite was measured and allocated to three grain size classes: $<2 \mathrm{~mm}$ (sand), $<0.5$ and $<1 \mathrm{~cm}$. Soil temperatures at lower depths than $-0.5 \mathrm{~cm}(-2$, -4 and $-10 \mathrm{~cm}$ ) were additionally recorded with thermistors (107, Campbell Scientific, Logan, UT, USA). All sensors types were connected to a data logger (CR10X, Campbell Scientific) that was programmed to collect data every $30 \mathrm{~s}$ and to record mean values at 10 and 30 min intervals.

\section{Heat tolerance}

Heat treatment to test heat tolerance was conducted in hot water baths (Thermomix Braun, Melsungen, Germany). All developmental stages were exposed for a duration of $30 \mathrm{~min}$, to a set of heat temperatures differing by $2 \mathrm{~K}$ ranging between the temperature at 0 and $100 \%$ heat damage $\left(36-60{ }^{\circ} \mathrm{C}\right)$. At each exposure temperature, ten replicates of each developmental stage were tested for heat tolerance. The heat tolerance of the seedling organs (roots, hypocotyl and cotyledons) was tested separately at each exposure temperature on three to five seedlings. The samples were placed on wet filter paper and plunged inside heat-durable and watertight plastic bags into the preheated water baths to bring them immediately to the exposure temperature as is standard in heat tolerance tests (Kreeb 1990). After a period of 5 days (exposure in the growth chamber), when heat damage symptoms had developed, viability of the samples was assessed. Viability was checked for the developmental stage samples as a whole and for single organs by a tetrazolium test (TTC). By this test (Ruf and Brunner 2003; Larcher et al. 2010; Marcante et al. 2012), dehydrogenase activity reduces the colourless tetrazolium salt to red-coloured triphenyl formazan, so that red-coloured cells and organs can be rated as viable (Larcher 1969).

The percentage of heat damage was calculated with image analysis software (OPTIMAS, 4.5, Media Cybernetics, Rockville, MD, USA) and then plotted against the treatment temperature. A classic logistic function was fitted to the data with P-Fit software (Biosoft, Durham, NC, USA):

$y=\operatorname{Min}+\frac{\operatorname{Max}-\operatorname{Min}}{1+e^{-k(X-X 50)}}$

where $X$ is the input variable (target temperature), $Y$ is the output variable (injury as a percentage), Min and Max are asymptotic upper and lower limits of the curve $(0,100 \%), X 50$ is the input variable at the inflection point (Min - Max)/2, and $k$ is a slope factor. Values of $X 50$ were read directly from the fitted curve and used as a measure of heat tolerance (i.e. taken as $\mathrm{LT}_{50}$, the lethal temperature $\left({ }^{\circ} \mathrm{C}\right)$ for half of the samples).

\section{Statistical analysis}

Statistics were performed using STATISTICA 6.1 (Stat. Soft Inc., Tulsa, OK, USA) and IBM SPSS STATISTICS (version 21, IBM, USA). Differences of heat tolerance $\left(\mathrm{LT}_{50}\right)$ between developmental stages (G1, G2 and G3), between species and between successional stages were assessed by the multivariate nonparametric Kruskal-Wallis ANOVA test. The heat hardening capacity of seedlings, field-grown versus laboratory grown seedlings, was tested with the nonparametric Mann-Whitney $U$ test.

Temperature maxima (half an hour means) were tested for normal distribution by the Shapiro-Wilk test. The homogeneity of variances was examined by the Levene test. Then, the effects of year, micropositioning of temperature sensors and grain size at the measurement spot on maximum temperature (half an hour means), were analysed by three-way ANOVA and the Duncan post hoc test.

Box plots show the median, the 25 and $75 \%$ quartiles, respectively, given by the lower and upper edges of boxes. Whiskers show the $95 \%$ confidence interval. Outliers are not shown.

\section{Results}

Heat tolerance of early developmental stages grown in the growth chamber

Across all species (Fig. 1), seeds (G1) were the most heat tolerant developmental stage followed by 


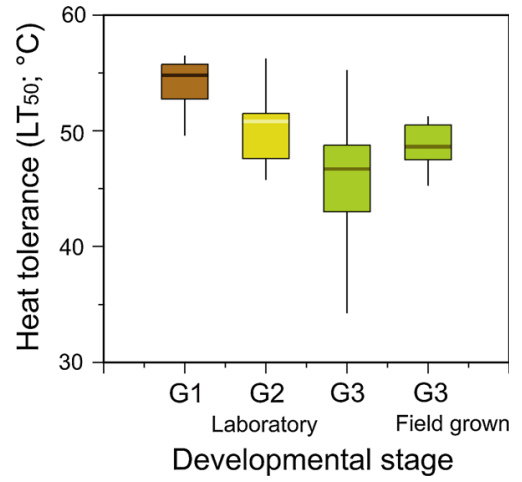

Fig. 1 Decrease in heat tolerance $\left(\operatorname{LT}_{50}{ }^{\circ} \mathrm{C}\right)$ during germination in a growth chamber from imbibed seeds (G1 brown) to germinated seeds ( $G 2$ yellow) and seedlings (G3 green) as compared to field-grown seedlings determined for all investigated species from the Rotmoos glacier foreland

germinated seeds (G2) and seedlings (G3; H(2, $96)=55.2, \quad p<0.001)$. During germination, the median $\mathrm{LT}_{50}$ decreased significantly by $4 \mathrm{~K}$ from $55{ }^{\circ} \mathrm{C}$ in seeds to $51{ }^{\circ} \mathrm{C}$ in germinated seeds and by $9 \mathrm{~K}$ to $46{ }^{\circ} \mathrm{C}$ in seedlings (see also Supplement 1 ).

The mean heat tolerance of the seeds varied between $49.3{ }^{\circ} \mathrm{C}$ for Saxifraga aizoides and $56.5^{\circ} \mathrm{C}$ for Persicaria vivipara bulbils followed by Arabis coerulea and Artemisia genipi (55.1 and $55.9^{\circ} \mathrm{C}$, respectively) that of germinated seeds between $44.8{ }^{\circ} \mathrm{C}$ for Artemisia genipi and $51.5^{\circ} \mathrm{C}$ for Geum reptans. Among the seedlings, those of Arabis coerulea, Achillea moschata and Persicaria vivipara were the most susceptible to heat $\left(40.6,43.1\right.$ and $43.4{ }^{\circ} \mathrm{C}$, respectively), while those of Trifolium pallescens and Poa alpina were the most heat tolerant ones (50.2 and $52.5^{\circ} \mathrm{C}$, respectively, Fig. 2).

The heat tolerance of all three developmental stages was relatively uniform only within the late successional species group, showing a general trend. Considerable variations were recognizable within the early successional species as well as within the pioneer group, following no overall trend. Among the pioneer seeds, Saxifraga aizoides exhibited the lowest heat tolerance (mean $=49.3{ }^{\circ} \mathrm{C}$ ) and Artemisia genipi the highest $\left(55.9^{\circ} \mathrm{C}\right.$, Fig. 2). The bulbils of Persicaria vivipara were the most tolerant ones within the early successional species $\left(56.5^{\circ} \mathrm{C}\right)$, being more tolerant than the seeds of the late successional species (mean $=54.2{ }^{\circ} \mathrm{C}$ ). Among the pioneer seedlings (G3), Arabis coerulea was the most susceptible

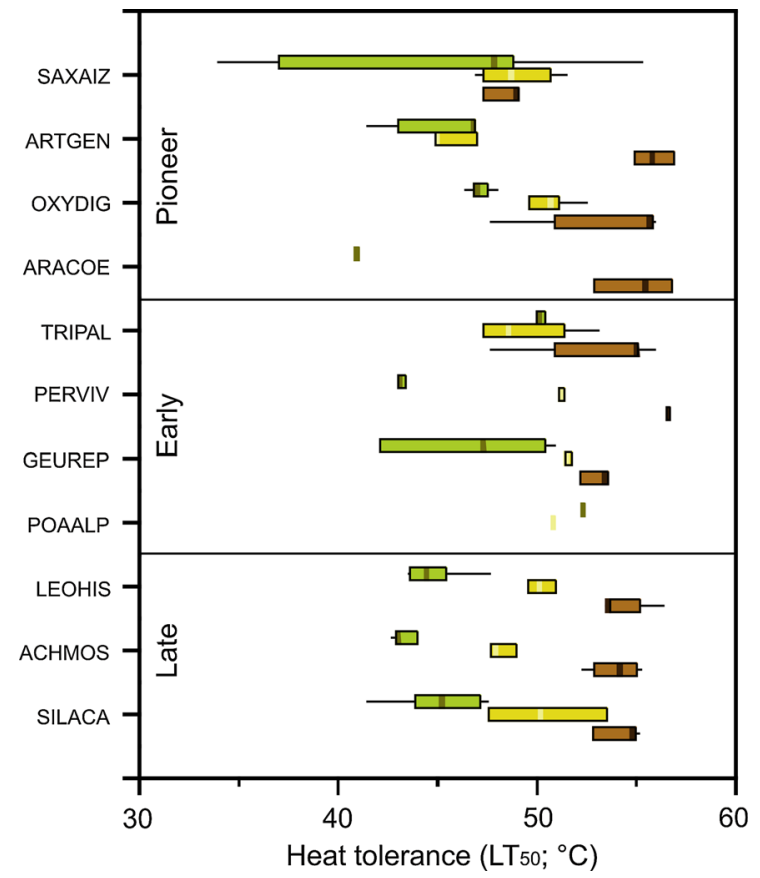

Fig. 2 Variability of heat tolerance $\left(\mathrm{LT}_{50} ;{ }^{\circ} \mathrm{C}\right)$ in different alpine plant species from the Rotmoos glacier foreland during early development: imbibed seeds (G1 brown), germinated seeds (G2 yellow) and seedlings (G3 green)

species $\left(40.6{ }^{\circ} \mathrm{C}\right)$, whereas Oxyria digyna was the most tolerant one $\left(46.9{ }^{\circ} \mathrm{C}\right)$. Seedling heat tolerance of the early successional species varied between $43.4^{\circ} \mathrm{C}$ (Persicaria vivipara) and $52.5^{\circ} \mathrm{C}$ (Poa alpina), that of the late successional species between $43.1{ }^{\circ} \mathrm{C}$ (Achillea moschata) and $45.2{ }^{\circ} \mathrm{C}$ (Silene acaulis).

In the seedling stage, significant differences in heat tolerance between different organs (cotyledons, hypocotyl and roots) were observed (KW-H(4, $259)=27.1, p<0.001$, Fig. 3). Across all species, the cotyledons turned out to be the most heat susceptible organ $\left(47.5^{\circ} \mathrm{C}\right)$, being significantly different $(p<0.01)$ from roots $\left(49.0^{\circ} \mathrm{C}\right)$ and hypocotyl $\left(49.5^{\circ} \mathrm{C}\right)$. Considering the species along the successional sequence, cotyledons of the pioneer and the early successional species had a higher heat tolerance compared to that of the late successional species (KW$\mathrm{H}(2,45)=12.8, p<0.01)$. At the species level, the pioneer species Artemisia genipi, Arabis coerulea and Saxifraga aizoides showed the same trend with a higher heat tolerance of roots and hypocotyl compared to cotyledons and seedlings as a whole. Within the early successional species Trifolium pallescens and 


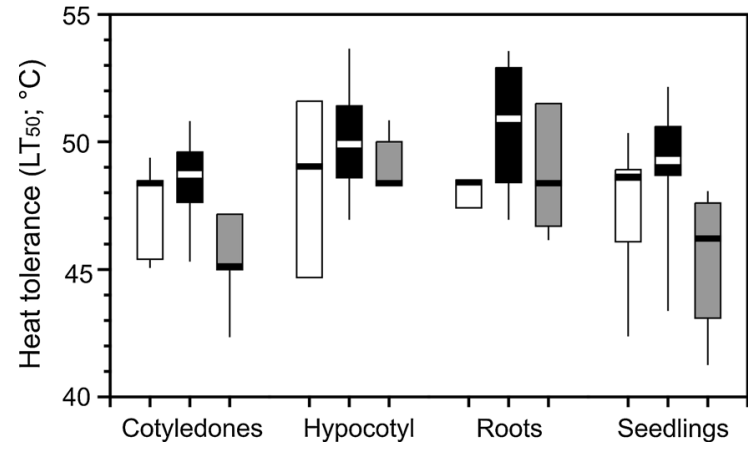

Fig. 3 Heat tolerance $\left(\mathrm{LT}_{50} ;{ }^{\circ} \mathrm{C}\right)$ of different organs of seedlings of species from the Rotmoos glacier foreland found at the pioneer (white), early (black) and late (grey) successional stages

Poa alpina, the hypocotyl was the most heat tolerant organ $(p<0.01)$, while Persicaria vivipara roots were significantly $(p<0.01)$ more heat tolerant than hypocotyl and cotyledons. Within the late successional species, Silene acaulis seedlings and cotyledons had a mean heat tolerance of $47.2^{\circ} \mathrm{C}$, while the roots tolerated up to $51.5^{\circ} \mathrm{C}(p<0.01)$.

Heat tolerance of seedlings grown in the field

Across all investigated glacier foreland species, median heat tolerance $\left(\mathrm{LT}_{50}\right)$ of the seedlings grown in the field was $48.8^{\circ} \mathrm{C}$ (see Fig. 1), being $2 \mathrm{~K}$ higher than that of seedlings cultivated in the growth chamber $\left(46.8{ }^{\circ} \mathrm{C}\right.$; KW-H $\left.(1,113)=44, p<0.001\right)$. Within the pioneer species, the heat tolerance of the seedlings grown in the field was significantly higher (with exception of Saxifraga aizoides) than that of seedlings grown in the growth chamber (KW-H (1$55)=16.2, p<0.01)$. Within the early successional species, only the seedlings of Persicaria vivipara grown in the field turned out to be more tolerant than those grown in the growth chamber (KW-H(1$12)=6.2, p<0.05)$. In contrast, seedlings of Poa alpina grown in the field showed a lower heat tolerance than those grown in the growth chamber (50.7 and $52.5^{\circ} \mathrm{C}$, respectively, KW-H(1$16)=11.5, p<0.001)$. Seedlings of the late successional species Achillea moschata and Silene acaulis grown in the field had a $3.2-2{ }^{\circ} \mathrm{C}$ higher heat tolerance than those grown in the growth chamber.

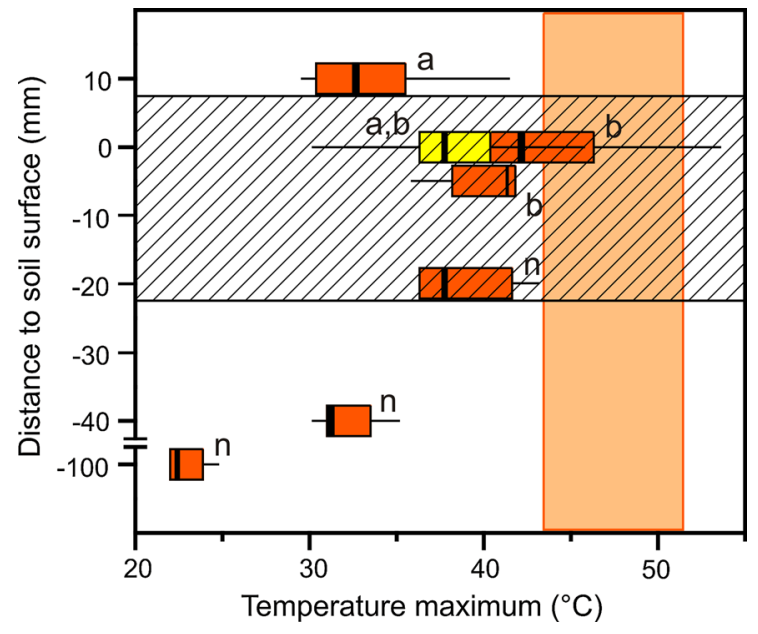

Fig. 4 Maximum temperatures (half an hour means) recorded at the ground surface $(0-0.5$ and $1 \mathrm{~cm})$, on the ground surface, below small stones $(0-0.5 \mathrm{~cm}$; yellow bar) and in the soil at a depth of $-0.5,-2,-4$ and $-10 \mathrm{~cm}$ during summer (June-JulyAugust) of four successive years (2007-2010) at the pioneer stage of the Rotmoos glacier foreland $(2,400 \mathrm{~m}$ asl). Vertical light orange bar gives the range of heat tolerances $\left(\mathrm{LT}_{50}\right)$ of the investigated field-grown seedlings. The horizontal hatched bar indicates the strata where seedlings establish. Different letters indicate significant differences $(n \ldots$ not tested)

Temperature conditions for germination at the field site

At the pioneer stage of the Rotmoos glacier foreland $(2,400 \mathrm{~m}$ asl $)$, the highest heat load was observed in the strata where seedlings germinate and establish (Fig. 4). During the 2007-2010, growing seasons highest maximum temperatures (half an hour means) were recorded in air close to the ground surface $(0-0.5 \mathrm{~cm})$. Temperature maxima were at mean $42.6{ }^{\circ} \mathrm{C}$. Maximum temperatures reached and occasionally exceeded heat tolerance determined for fieldgrown seedlings. In contrast, ground surface temperatures recorded at the ground surface $(0-0.5 \mathrm{~cm})$ with the sensor tip covered by a small stone (yellow bar in Fig. 4) were considerably mitigated. Temperature recordings at such microsites reveal approximately $4 \mathrm{~K}$ reduced maximum temperatures, i.e. $38.7{ }^{\circ} \mathrm{C}$. This indicates large differences between microsites at the ground surface with respect to the maximum heat load. As like, $1 \mathrm{~cm}$ above the ground surface in air, temperature maxima $\left(34.0^{\circ} \mathrm{C}\right)$ were too low to cause heat damage to seedlings. Also at -0.5 and $-2 \mathrm{~cm}$ temperature maxima were too low for heat damage to 


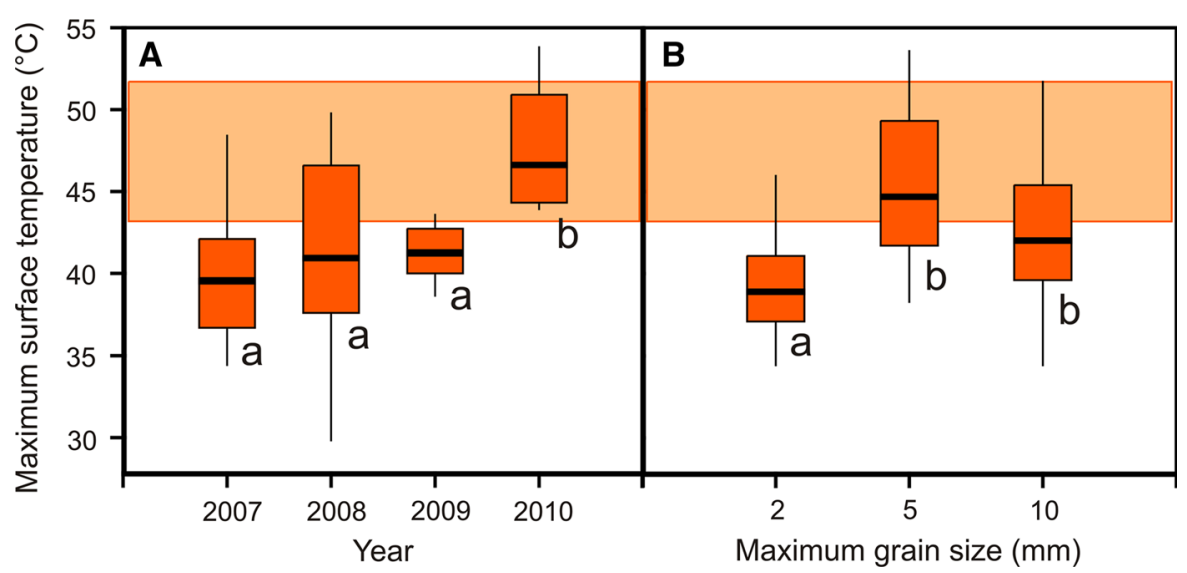

Fig. 5 Maximum temperature (half an hour means) recorded at the ground surface $(0-0.5 \mathrm{~cm})$ during summer (June-JulyAugust) at the pioneer stage of the Rotmoos glacier foreland $(2,400 \mathrm{~m}$ asl). a Maximum temperatures differed between the years (2007-2010). b Maximum temperatures were affected by

the roots of seedling (Fig. 4). With increasing soil depth heat became successively reduced down to a moderate value of $23.1{ }^{\circ} \mathrm{C}$ at $-10 \mathrm{~cm}$ (Fig. 4).

Ground surface temperatures

As ground surface temperatures appear most critical for heat survival, these temperature records were further analysed. Interannual differences in maximum ground surface temperatures were highly significant (Supplement 2). 2010 was the hottest year within the investigation period. In 2010, $100 \%$ of temperature sensors recorded temperature maxima that were in the range or even exceeded the heat tolerance range of field-grown seedlings (Fig. 5a). A minor heat load was observed in 2007, 2008 and 2009: in these years, on $23.1,38.5$ and $9.1 \%$ of measurement spots, respectively, temperature maxima would have been high enough to cause heat damage $\left(>43.2^{\circ} \mathrm{C}\right)$. Throughout 2007-2009 at mean on $70.7 \%$ of measured microsites, maximum temperatures were not harmful.

Grain size was also found to be a significant factor for temperature maxima (Fig. 5b). On sandy ground surfaces $(<2 \mathrm{~mm})$, ground surface temperature maxima hardly $(16.7 \%)$ extended into the heat tolerance range of field-grown seedlings. At microsites with gravel $(<5$ or $<10 \mathrm{~mm})$, most temperature maxima $(63.2 \%)$ measured in air between gravel were within the range where heat injury to seedlings occurs. grain size: on sand $(<2 \mathrm{~mm})$, maximum temperatures were lower than on microsites with gravel diameters $<5$ and $<10 \mathrm{~mm}$. Horizontal light orange bar gives the range of heat tolerances $\left(\mathrm{LT}_{50}\right)$ of the investigated field-grown seedlings. Different letters indicate significant differences

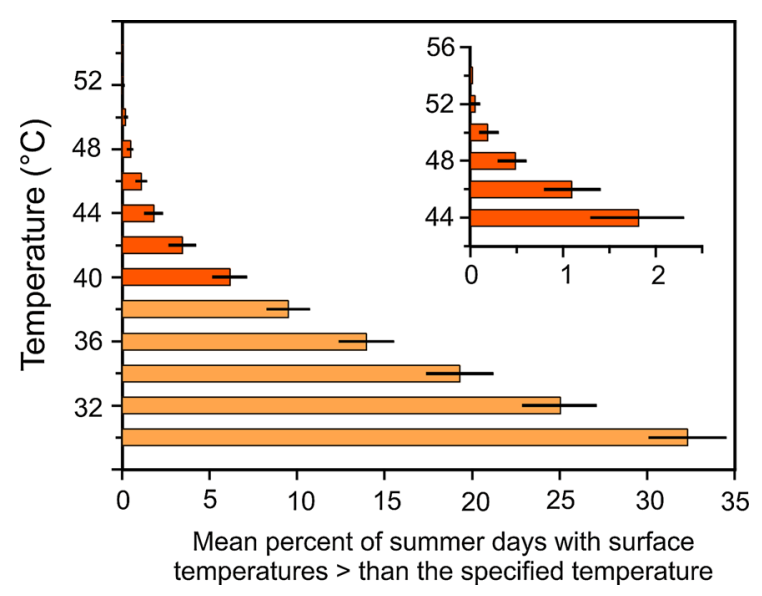

Fig. 6 Mean per cent of summer days ( $\% \pm$ SE; June-JulyAugust; 2007-2010) with ground surface $(0-0.5 \mathrm{~cm})$ temperature maxima (half an hour means) greater than the specified temperature. Ground surface temperatures were recorded at the pioneer stage of the Rotmoos glacier foreland $(2,400 \mathrm{~m}$ asl). Temperatures potentially inducing heat damage in seedlings are coloured in a darker orange color

Temperature maxima recorded by sensors tips positioned below gravel extended to a lesser extent $(14.3 \%)$ into the heat tolerance range.

Overall warm $\left(>30^{\circ} \mathrm{C}\right)$ ground surface temperatures at the pioneer stage of the Rotmoos glacier foreland occurred at high frequency $(>32.3 \%)$ during summers 2007-2010 (Fig. 6). Critically high temperature maxima $\left(30 \mathrm{~min}>40{ }^{\circ} \mathrm{C}\right)$ occurred at a 
frequency of $6.2 \%$, in 2010 at $11.0 \%$ of investigated days from June-August.

\section{Discussion}

To our knowledge, these are the first results dealing with heat tolerance of early developmental stages of alpine plants. Imbibed seeds were found to be the most heat tolerant developmental stage investigated, followed by germinated seeds and seedlings. Still, dry seeds can survive higher temperatures $\left(59-74{ }^{\circ} \mathrm{C}\right.$; Wildner-Eccher and Larcher, unpublished; cited in Neuner and Buchner 2012). With a heat tolerance of $55{ }^{\circ} \mathrm{C}$ (median), imbibed seeds must be considered to be hardly endangered by maximum temperatures recorded during the investigated years in the glacier foreland (highest half an hour mean value: $54.1{ }^{\circ} \mathrm{C}$ ). Even seeds with lowest heat tolerance such as those of Saxifraga aizoides (range $47.3-53.0{ }^{\circ} \mathrm{C}$ ) may be able to survive. The seeds of this species are the smallest ones in the glacier foreland (seed mass $0.04 \mathrm{mg}$, Schwienbacher and Erschbamer 2002; Schwienbacher et al. 2010). They can easily get buried and thus are able to avoid high temperature events at the ground surface. Together with most of the other glacier foreland species Saxifraga aizoides forms a persistent seed bank (Marcante et al. 2009b; Schwienbacher et al. 2010; 2011; 2012). Already at $-0.5 \mathrm{~cm}$ soil depth, the severity of heat is considerably decreased. Heat stress might be a problem for seeds not forming a persistent seed bank, such as those of Oxyria digyna, Geum reptans and Persicaria vivipara (Marcante et al. 2009b; Schwienbacher et al. 2010). However, heat tolerance of seeds of these species was found to be higher $53.2{ }^{\circ} \mathrm{C}$ (Oxyria), $51.7^{\circ} \mathrm{C}$ (Geum) and $56.5^{\circ} \mathrm{C}$ (Persicaria). All in all, in the glacier foreland although not completely excludable, imbibed seeds appear to have a low risk of being lost by heat stress.

With the onset of germination, the vulnerability to heat increases. In laboratory grown seedlings, median heat tolerance was decreased by $4 \mathrm{~K}$ in germinated seeds and by $9 \mathrm{~K}$ in seedlings. Summer frosts were already outlined as major constraint in alpine environments (Körner 2003; Marcante et al. 2012). Our results add heat as a possible impeding environmental factor. Intraspecifically seedlings with a higher and lower heat tolerance can be differentiated, Poa alpina $\left(52-55^{\circ} \mathrm{C}\right)$ and Trifolium pallescens $\left(50-51{ }^{\circ} \mathrm{C}\right)$ being the most heat tolerant species. Poa alpina was identified as ubiquitous species in the glacier foreland (Marcante et al. 2009a; Winkler et al. 2010) with seedling establishment along the whole glacier foreland, but with highest dominance at the early successional stage (Raffl et al. 2006; Schwienbacher et al. 2012). Grasses are generally predicted to be favoured by climate change (Walker et al. 2006; Shevtsova et al. 2009), probably also because of their generally increased heat tolerance (Buchner and Neuner 2001; Neuner and Buchner 2012) that is here corroborated for their seedlings. The comparatively high heat tolerance contributes to the explanation of species' success along the successional sequences. The same holds for Trifolium pallescens that approaches quite fast recently deglaciated areas. Among more heat susceptible seedlings, the pioneer species Saxifraga aizoides showed tolerance minima of $34{ }^{\circ} \mathrm{C}$, but also maxima up to $56{ }^{\circ} \mathrm{C}$. In the arctic tundra, Saxifraga cernua exhibited a negative response to an artificially created heat pulse (temperatures above $44{ }^{\circ} \mathrm{C}$, Graae et al. 2009). Even stronger negative effects of a heat pulse were shown for Persicaria vivipara (Graae et al. 2009). In our experiment, this species showed a mean tolerance of $43{ }^{\circ} \mathrm{C}$.

Mean heat tolerance of field-grown seedlings $\left(\mathrm{LT}_{50} ; 46.1-50.7{ }^{\circ} \mathrm{C}\right.$ ) was found to be in the range of heat tolerance reported for adult alpine plants (vegetative parts: $\mathrm{LT}_{50} 42.0-64.0{ }^{\circ} \mathrm{C}$ compiled in Neuner and Buchner 2012; reproductive parts: $\mathrm{LT}_{50}$ 43.6-51.0 ${ }^{\circ} \mathrm{C}$ Ladinig, Neuner and Wagner unpubl.). For Oxyria digyna, Poa alpina, Geum reptans and Silene acaulis, heat tolerance data from adult individuals are available (Neuner and Buchner 2012). While Oxyria digyna and Geum reptans seedlings appear similarly heat tolerant as adults, Poa alpina and Silene acaulis seedlings showed a lower heat tolerance than reported for adults: 50.7 versus $56.2^{\circ} \mathrm{C}$ and 47.2 versus $50.7^{\circ} \mathrm{C}$, respectively. It comes clear that developmental changes in heat tolerance need not be neglected when the establishment of plants is investigated.

It is also necessary to consider all organs as survival often depends on the most susceptible plant organ. Interestingly for the seedling, the cotyledons were detected to be the most heat susceptible ones, although they expand in the ground surface stratum where they get exposed to the most extreme temperature maxima. 
Still, cooling of cotyledons by transpiration may suffice to allow survival of heat. However, transpiration relies on a sufficient water supply that is successively reduced during sunny and hot periods. In alpine zones, the topsoil is known to desiccate even in the wettest mountains (Körner 2003). The topsoil is in turn the stratum were seedling roots initially may take up their water and in the pioneer stage top layers of undeveloped soils may additionally have only a poor amount of capillary water. Hence, water shortage and consequent reduced transpiration during hot days must be considered to be highly probable at the pioneer stage. Roots and hypocotyl were more heat tolerant and can be expected to better survive the moderated temperatures in the upper ground strata. Still, after heat damage to cotyledons, the recuperation capacity from the remainder parts, although not completely impossible, must be considered rather low.

Heat tolerance of seedlings cultivated in the growth chamber was significantly lower in six out of eleven species (at mean lower by $2.0 \mathrm{~K}$ ). In seedlings, cultivated in the growth chamber minimum heat tolerance could be as low as $33.5^{\circ} \mathrm{C}$ (Saxifraga aizoides). Minimum heat tolerance was in 6 out of 11 species lower than the lowest heat tolerance ever reported for vegetative parts of adult alpine plants (42 ${ }^{\circ} \mathrm{C}$; Neuner and Buchner 2012). This demonstrates that for ecological interpretations, tests on field-grown plants are inevitably necessary. This intraspecific variability of heat tolerance between seedlings cultivated in the growth chamber and that grown at the field site is a consequence of heat hardening. In nature on alpine sites, heat hardening can occur at high rates $4.7 \mathrm{~K} / \mathrm{d}$ within the species-specific heat tolerance range (6-11.7 K, Buchner and Neuner 2003). Heat hardening is observed when critically high temperature thresholds are surpassed (Alexandrov 1977). Threshold temperatures for the onset of heat hardening in higher plants are temperatures exceeding $30-32{ }^{\circ} \mathrm{C}$ (e.g.: Silene acaulis, Neuner et al. 2000). In the pioneer stage of the Rotmoos glacier foreland such temperatures $\left(>30^{\circ} \mathrm{C}\right)$ frequently $(32.3 \%)$ occur on the ground surface were seedlings establish. This may explain our result of a mostly increased heat tolerance of field-grown seedlings and emphasizes the necessity of field studies.

For survival and persistence of seedlings, microsites (Titus and Tsuyuzaki 2003; Chad and del Moral 2005; Akhalkatsi et al. 2006; Mayer and Erschbamer
2011) or safe site regeneration niches (Bell and Bliss 1980; Körner 2003; Shevtsova et al. 2009) are essentially necessary and offer in fine-scale environments so-called microtopographic shelters (Batllori et al. 2009). Our ground surface temperature records highly corroborate these fine-scale environmental differences in temperatures on the ground surface. Shading by a small stone can mitigate the temperature maximum significantly. Depending on the microstructure of the ground surface (sand or gravel) and the positioning of temperature sensors (in air or below small stones: $0-0.5 \mathrm{~cm}$ ), maximum temperatures in small distance could vary between 31.9 and $49.3{ }^{\circ} \mathrm{C}$ (mean of 2007-2010). By this roughness of the soil, surface does not only govern deposition of seeds (Chambers et al. 1991; Chambers 1995) but also offers safe sites for germination (Chambers et al. 1990). Our results nicely demonstrate that microsites protected from heat can potentially promote survival. Similarly, facilitation effects by established plants were highlighted (Callaway et al. 2002; Elmarsdottir et al. 2003; Cavieres et al. 2005; 2006; 2007), creating "thermally stable sites" (Cavieres et al. 2007). Also in the glacier foreland, colonization depends on facilitation by established plants or stones (Niederfriniger Schlag and Erschbamer 2000; Erschbamer et al. 2008). Our results confirm that small stones are able to reduce maximum temperatures below them which may in certain situations suffice to survive heat. In contrast, the air between larger particles $(<5$ and $<10 \mathrm{~mm})$ is wind sheltered which reduces convection and causes considerable overheating to potentially critically high lethal temperatures. Chambers (1995) clearly showed that alpine seedlings were able to emerge at particle sizes of $<0.5$ to $4-8 \mathrm{~mm}$. However, none of these seedlings survived in particle sizes larger than 1-2 mm, i.e. establishment seems to be possible only in fine-grained substrate. According to the author, larger particle sizes failed to provide 'biological requirements'. We suggest that this could be due to overheating of air between larger particles.

Overheating of the ground surface was particularly pronounced in 2010, indicating significant differences between observation years. The heat wave of 2010 has already been recognized (Barriopedro et al. 2011). Ground surface temperature maxima (half an hour means) exceeded the lowest and highest heat tolerance of field-grown seedlings $\left(43.2-51.7^{\circ} \mathrm{C}\right)$ and reached a maximum of $54.1{ }^{\circ} \mathrm{C}$. In 2010 , temperature maxima 
were higher than $43.2{ }^{\circ} \mathrm{C}$ at all measurement spots at the ground surface $0-0.5 \mathrm{~cm}$ in air, but additionally on $80 \%$ of microsites $0-0.5 \mathrm{~cm}$ where temperatures were recorded below a small stone. Until present, negative effects of heat waves on plants have scarcely been reported for alpine ecosystems (De Boeck et al. 2010, 2011, Abeli et al. 2012). Nevertheless, for vegetative above-ground plant parts of alpine species, heat damage has been observed to occur naturally at alpine field sites when after several sunny days water shortage reduces transpirational cooling (Larcher and Wagner 1976; Neuner et al. 1999; Buchner and Neuner 2003; Gauslaa 1984; Körner 2003). Water supply to seedlings on the undeveloped soils in the glacier foreland is poor (Schwienbacher et al., unpubl.). Generally, moist microenvironments could counteract overheating of the soil surface. However, the sandy ground material of the study site dries out quickly. Drought and resultant consequences appear to be the most important inhibitors of seedling recruitment and survival (Schwienbacher et al., unpubl. data). During sunny periods, lacking water availability in the upper soil strata may reduce transpirational cooling bringing seedlings even into higher risk of heat damage. Without transpiration, leaves tend to overheat. Even without overheating, our ground surface temperature records per se indicate a considerable risk of heat damage to seedlings in alpine glacier forelands due to the dryness of the substrate.

\section{Conclusions}

The results of our experiment suggest that heat likely affects the recruitment of seedlings under water shortage in pioneer stages of glacier forelands, whereas heat effects on imbibed seeds may have comparatively minor importance. The heat tolerance during and after germination does not suffice to survive summer heat waves (i.e. events predicted to be more and more frequent in the course of climate warming) at the bare ground surface when water availability is reduced. Heat may at least partly explain the high seedling mortality recognized in recently deglaciated terrain of the glacier foreland. Locally, seedlings may profit from microenvironmental mitigation of ground surface heat caused by small stones or other safe sites that mitigate heat by shading, but additionally may provide enough water allowing transpirational cooling.
Acknowledgments This research was funded by the Austrian Science Fund (FWF): P19090-B16. We thank the Alpine Research Centre Obergurgl for providing infrastructure and research facilities. We are grateful to Mag. Erich Schwienbacher for seed collection and assistance in the field.

Open Access This article is distributed under the terms of the Creative Commons Attribution License which permits any use, distribution, and reproduction in any medium, provided the original author(s) and the source are credited.

\section{References}

Abeli T, Rossi G, Gentili R, Gandini M, Mondoni A, Cristofanelli $P$ (2012) Effect of the extreme summer heat waves on isolated populations of two orophitic plants in the north Apennines (Italy). Nordic J Bot 30:109-115

Akhalkatsi M, Abdaladze O, Nakhutsrishvili G, Smith WK (2006) Facilitation of seedling microsites by Rhododendron caucasicum extends the Betula litwinowii alpine treeline, Caucasus mountains, Republic of Georgia. AAAR 38:481-488

Alexandrov VY (1977) Cells, molecules and temperature. Ecological studies, 21. Springer, Berlin

Barriopedro D, Fischer EM, Luterbacher J, Trigo RM, GarcíaHerrera (2011) The hot summer of 2010: redrawing the temperature record map of Europe. Science 332:220-224

Batllori E, Camarero JJ, Ninot JM, Gutiérrez E (2009) Seedling recruitment, survival and facilitation in alpine Pinus uncinata tree line ecotones. Implications and potential responses to climate warming. Glob Ecol Biogeogr 18:460-472

Bell KL, Bliss C (1980) Plant reproduction in a high arctic environment. Arct Alp Res 12:1-10

Buchner O, Neuner G (2001) Determination of heat tolerance: a new equipment for field measurements. J Appl Bot 75:130-137

Buchner O, Neuner G (2003) Variability of heat tolerance in alpine plant species measured at different altitudes. Arct Antarc Alp Res 35:411-420

Callaway RM (2007) Positive interactions and interdependence in plant communities. Springer, Dordrecht

Callaway RM, Brooker RW, Choler P, Kikvidze Z, Lortie CJ, Michalet R, Paolini L, Pugnaire FI, Newingham B, Aschehoug ET, Armas C, Kikvidze D, Cook BJ (2002) Positive interactions among alpine plants increase with stress. Nature 417:844-848

Cavieres LA, Quiroz CL, Molina-Montenegro MA, Muñoz AA, Pauchard A (2005) Nurse effect of the native cushion plant Azorella monantha on the invasive non-native Taraxacum officinale in the high-Andes of central Chile. Perspect Plant Ecol Evol Syst 7:217-226

Cavieres LA, Badano EI, Sierra-Almeida A, Gómez-González S, Molina-Montenegro MA (2006) Positive interactions between alpine plant species and the nurse cushion plant Laretia acaulis do not increase with elevation in the Andes of central Chile. New Phytol 169:59-69

Cavieres LA, Badano EI, Sierra-Almeida A, Molina-Montenegro MA (2007) Microclimatic modifications of cushion plants and their consequences for seedling survival of 
native and non-native herbaceous species in the high Andes of Central Chile. AAAR 39:229-236

Chad JC, del Moral R (2005) Effects of microsite conditions on seedling establishment on the foreland of Coleman Glacier, Washington. J Veg Sci 16:293-300

Chambers JC (1995) Disturbance, life history strategies, and seed fates in alpine herbfield communities. Am J Bot 82:421-433

Chambers JC, MacMahon JA, Brown RW (1990) Alpine seedling establishment: the influence of disturbance type. Ecology 7:1323-1341

Chambers JC, MacMahon JA, Haefner JH (1991) Seed entrapment in alpine ecosystems: effects of soil particle size and diaspore morphology. Ecology 72:1668-1677

Choler P, Michalet R, Callaway RM (2001) Facilitation and competition on gradients in alpine plant communities. Ecology 82:3295-3308

De Boeck HJ, Dreesen FE, Janssens IA, Nijs I (2010) Climatic characteristics of heat waves and their simulation in plant experiments. Glob Change Biol 16:1992-2000

De Boeck HJ, Dreesen FE, Janssens IA, Nijs I (2011) Wholesystem responses of experimental plant communities to climate extremes imposed in different seasons. New Phytol 189:806-817

Elmarsdottir A, Aradottir AL, Trlica MJ (2003) Microsite availability and establishment of native species on degraded and reclaimed sites. J Appl Ecol 40:815-823

Erschbamer B, Niederfriniger Schlag R, Winkler E (2008) Colonization processes on a central Alpine glacier foreland. J Veg Sci 19:855-862

Fischer MA, Oswald K, Adler W (2008) Exkursionsflora für Österreich, Liechtenstein, Südtirol, 3rd edn. Biologiezentrum Oberösterr, Landesmuseen

García-Herrera R, Díaz J, Trigo RM, Luterbacher J, Fischer EM (2010) A review of the European summer heat wave of 2003. Crit Rev Environ Sci Technol 40:267-306

Gauslaa Y (1984) Heat resistance and energy budget in different Scandinavian plants item citation. Holarct Ecol 7:5-78

Graae BJ, Ejrnaes R, Marchand FL, Milbau A, Shevtsova A, Beyens L, Nijs I (2009) The effect of an early-season shortterm heat pulse on plant recruitment in the Arctic. Polar Biol 32:1117-1126

Kikvidze Z, Pugnaire FI, Brooker RW, Choler P, Lortie CJ, Michalet R, Callaway RM (2005) Linking patterns and processes in alpine plant communities: a global study. Ecology 86:1395-1400

Körner C (2003) Alpine plant life. Functional plant ecology of high mountain ecosystems, Springer

Körner C, Cochrane P (1983) Influence of plant physiognomy on leaf temperature on clear midsummer days in the snowy mountains, south-eastern Australia. Acta Oecol 4:17-124

Kreeb KH (1990) Methoden zur Pflanzenökologie und Bioindikation. Gustav Fischer Verlag, Jena

Larcher W (1969) Increase in ability to become frost resistant during ageing in Quercus ilex. Planta 88:130-135

Larcher W (2012) Bioclimatic temperatures in the High Alps. In: Lütz C (ed) Plants in Alpine regions. Springer, Wien, pp 21-28. doi:10.1007/978-3-7091-0136-0_3

Larcher W, Wagner J (1976) Temperaturgrenzen der CO2Aufnahme und Temperaturresistenz der Blätter von
Gebirgspflanzen im vegetationsaktiven Zustand. Oecol Plant 11:361-374

Larcher W, Wagner J (2009) High mountain bioclimate: temperatures near the ground recorded from the timberline to the nival zone in the Central Alps. Contrib Nat Hist Berne 12:857-874

Larcher W, Wagner J (2010) Temperatures in the life zones of the Tyrolean Alps. In: Sitzungsberichte. Österreichische Akademie der Wissenschaften, Mathematisch-Naturwissenschaftliche Klasse Abteilung I, Biologische Wissenschaften und Erdwissenschaften 213:31-51

Larcher W, Kainmüller C, Wagner J (2010) Survival types of high mountain plants under extreme temperatures. Flora 205:3-18. doi:10.1016/j.flora.2008.12.005

Marcante S, Winkler E, Erschbamer B (2009a) Population dynamics along a primary succession gradient: do alpine species fit into demographic succession theory? Ann Bot 103:1129-1143

Marcante S, Schwienbacher E, Erschbamer B (2009b) Genesis of a soil seed bank on a primary succession in the Central Alps (Ötztal, Austria). Flora 204:434-444

Marcante S, Sierra-Almeida A, Spindelböck J, Erschbamer B, Neuner G (2012) Frost as a limiting factor for recruitment and establishment of early developmental stages in an alpine glacier foreland? J Veg Sci 23:858-868. doi:10. 1111/j.1654-1103.2012.01411.x

Matthews JA (1992) The ecology of recently deglaciated terrain. Cambridge University Press, Cambridge, UK, A geological approach to glacier forelands and primary succession

Mayer R, Erschbamer B (2011) Seedling recruitment and seed-/ microsite limitation in traditionally grazed plant communities of the alpine zone. Basic Appl Ecol 12:10-20

Neuner G, Buchner O (2012) Dynamic of tissue heat tolerance and thermotolerance of PS II in alpine plants. In: Lütz C (ed) Plants in alpine regions: cell Physiology of adaptation and survival strategies. Springer, Wien, pp 61-74. doi:10. 1007/978-3-7091-0136-0_6

Neuner G, Braun V, Buchner O, Taschler D (1999) Leaf rosette closure in the alpine rock species Saxifraga paniculata Mill.: significance for survival of drought and heat under high irradiation. Plant Cell Environ 22:1539-1548. doi:10. 1046/j.1365-3040.1999.00508.x

Neuner G, Buchner O, Braun V (2000) Short-term changes in heat tolerance in the alpine cushion plant Silene acaulis ssp. excapa [All.] J. Braun at different altitudes. Plant Biol 2:677-683

Niederfriniger Schlag R, Erschbamer B (2000) Germination and establishment of seedlings on a glacier foreland in the Central Alps, Austria. Arc Antarc Alp Res 32:270-277

Raffl C, Erschbamer B (2004) Comparative vegetation analyses of two transects crossing a characteristic glacier valley in the Central Alps. Phytocoenologia 34: 225-240

Raffl C, Mallaun M, Mayer R, Erschbamer B (2006) Vegetation succession pattern and diversity changes in a glacier valley, Central Alps, Austria. AAAR 38:421-428

Ruf M, Brunner I (2003) Vitality of tree fine roots: re-evaluation of the tetrazoliumtest. Tree Physiol 23:257-263

Salisbury FB, Spomer GG (1964) Leaf temperatures of alpine plants in the field. Planta 60:497-505 
Schwienbacher E, Erschbamer B (2002) Longevity of seeds in a glacier foreland of the Central Alps: a burial experiment. Bull Geobot Inst ETH 68:63-71

Schwienbacher E, Marcante S, Erschbamer B (2010) Alpine species seed longevity in the soil in relation to seed size and shape: a 5-year burial experiment in the Central Alps. Flora 205:19-25

Schwienbacher E, Navarro-Cano JA, Neuner G, Erschbamer B (2011) Seed dormancy in alpine species. Flora 206:845-856

Schwienbacher E, Navarro-Cano JA, Neuner G, Erschbamer B (2012) Correspondence of seed traits with niche position in glacier foreland succession. Plant Ecol 213:371-382

Shevtsova A, Graae BJ, Jochum T, Milbau A, Kockelbergh F, Beyens L, Nijs I (2009) Critical periods for impact of climate warming on early seedling establishment in subarctic tundra. Glob Change Biol 15:2662-2680

Titus JH, Tsuyuzaki S (2003) Distribution of plants in relation to microsites on recent volcanic substrates on Mount Koma, Hokkaido, Japan. Ecol Res 18:91-98

Turner H (1958) Maximaltemperaturen oberflächennaher Bodenschichten an der alpinen Waldgrenze. Wald und Leben 10:1-12
Walck JL, Hidayati SN, Dixon KW, Thompson K, Poschlod P (2011) Climate change and plant regeneration from seed. Glob Change Biol 17:2145-2161

Walker MD, Wahren CH, Hollister RD, Henry GHR, Ahlquist LE, Alatalo JM, Bret-Harte MS, Calef MP, Callaghan TV, Carroll AB, Epstein HE, Jónsdottir IS, Klein JA, Mangússon B, Molau U, Oberbauer SF, Rewa SP, Robinson $\mathrm{CH}$, Shaver GR, Suding KN, Thompson CC, Tolvanen A, Totland Ø, Turner PL, Tweedie CE, Webber PJ, Wookey PA (2006) Plant community responses to experimental warming across the tundra biome. PNAS 103:1342-1346

Welling P, Tolvanen A, Laine K (2005) Plant traits: their role in the regeneration of alpine plant communities in sub-arctic Finland. J Veg Sci 16:183-190

Winkler E, Marcante S, Erschbamer B (2010) Demographic consequences of the two reproductive modes in Poa alpina L. along a primary succession gradient in the Central Alps. AAAR 43:227-235 